\title{
KONTRIBUSI EKONOMI PENGOLAHAN LOGAM MULIA DI DESA BATU PUTIH KECAMATAN TALIWANG KABUPATEN SUMBAWA BARAT TERHADAP MINAT REMAJA SEKOLAH MELANJUTKAN PENDIDIKANNYA
}

\author{
Mujizat Ino \\ Universitas Negeri Malang \\ mujizatgivari@gmail.com
}

\begin{abstract}
ABSTRAK
Penelitian ini bertujuan untuk mendreskripsikan (1) Sejarah sektor pengolahan logam mulia di Desa Batu Putih Kecamatan Taliwang Kabupaten Sumbawa Barat, (2) minat belajar remaja usia sekolah yang bekerja di sektor pengolahan logam mulia, (3) kontribusi ekonomi remaja yang bekerja sambilan di pengolahan logam mulia terhadap kelanjutan pendidikan. Penelitian ini menggunakan metode kualitatif yang bersifat deskriptif. Penelitian ini dilakukan di Desa Batu Putih Kecamatan Taliwang Kabupaten Sumbawa Barat. Hasil penelitian ini adalah: (1) Hasil penelitian ini menunjukkan bahwa sejarah usaha pengolahan logam mulia di Desa Batu Putih berawal dari adanya penemuan kandungan bahan galian emas di daerah lain oleh PT. Newmont pada tahun 1995. Adanya penelitian itulah masyarakat ikut menambang secara tradicional dan mengalami perkembangan hingga saat ini, (2) Mengenai remaja yang ikut bekerja di pengolahan logam mulia masih tetap memiliki minat belajar yang baik. Hal ini ditunjang oleh beberapa faktor. Pertama, menganggap bekerja hanya sebagai pekerjaam sampingan, Kedua, tetap fokus untuk belajar meski sudah bekerja. Beberapa faktor tersebut juga didukung oleh manajemen waktu antara belajar dan bekerja dengan baik, (3) Bekerja di pengolahan logam mulia tidak memberikan kontribusi yang signifikan terhadap kelanjutan pendidikan remaja usia sekolah yang bekerja. Hal ini dikarenakan remaja masih bergantung kepada orang tua dan hasil dari bekerja digunakan hanya untuk memnuhi kebutuhan sehari-hari.
\end{abstract}

Kata kunci : Pengolahan Logam Mulia, Minat Belajar, Kontribusi Ekonomi, Kelanjutan Pendidikan

\section{PENDAHULUAN}

Kecamatan Taliwang merupakan kecamatan dengan laju pertumbuhan penduduk tertinggi di Kabupaten Sumbawa Barat. Mulai tahun 2016 sampai dengan 2017, Kecamatan Taliwang memiliki laju pertumbuhan tertinggi di Kabupaten Sumbawa Barat. Desa Batu Putih merupakan salah satu desa yang berada di Kecamatan Taliwang Kabupaten Sumbawa yang mempunyai kekayaan alam yang dimanfaatkan oleh masyarakat sekitar. Desa Batu Putih terletak di bagian barat Kecamatan Taliwang lebih tepatnya terletak di dataran tinggi, dengan luas wilayah $4,87 \mathrm{~km} 2$. Disebut batu putih karena daerah tersebut memang memiliki kandungan batu kapur yang tersebar hampir diseluruh gunung yang berada di Desa Batu Putih.

Potensi alam yang ada di Desa Batu Putih meliputi sektor pertanian, perternakan, dan tambang. Tambang yang dimaksudkan adalah tambang batu kapur, sedangkan emas yang dikelola di Batu Putih tidak berasal dari kekayaan alam Desa Batu Putih melainkan diambil dari gunung yang terdapat di Desa Lamunga.

Keberadaan tambang rakyat di Desa Batu Putih Kecamatan Taliwang memiliki dampak positif terhadap masyarakat Desa Batu Putih. Dampak positif dari pertambangan rakyat itu adalah selain dapat menambah kesejahteraan masyarakat dibidang ekonomi juga dapat memberikan pendapatan kepada daerah berupa pendapatan asli daerah dan memunculkan lapangan pekerjaan baru yang mudah bagi masyarakat. Selain dampak positif, pertambangan emas di Desa Batu Putih Kecamatan Taliwang juga memiliki dampak negatif yakni banyaknya remaja usia sekolah kemudian juga tertarik bekerja di sektor pertambangan tersebut karena pertambangan rakyat tidak mengisyaratkan usia untuk bekerja.

Ketertarikan remaja usia sekolah untuk memasuki usaha pertambangan rakyat di Desa Batu Putih berbahaya tidak hanya dilihat dari sisi keselamatan kerja tetapi juga minat belajar mereka di Sekolah bagi mereka yang memang masih duduk di bangku sekolah karena dikhawatirkan akan putus sekolah, remaja atau anak-anak yang bersekolah akan lebih cenderung putus sekolah ketika mereka menggabungkan antara sekolah dan bekerja dikarenakan lingkungan kerja yang menjanjikan serta kondusif untuk seusia remaja sekolahan. 
Focus: Jurnal

Pekerjaan Sosial

\section{RUMUSAN MASALAH}

1. Bagaimana Sejarah sektor pengolahan logam mulia di Desa Batu Putih Kecamatan

Taliwang Kabupaten Sumbawa Barat?

2. Bagaimana minat belajar remaja usia sekolah yang bekerja di sektor pengolahan logam mulia?

3. Bagaimana kontribusi ekonomi remaja yang bekerja sambilan di pengolahan logam mulia terhadap kelanjutan pendidikannya?

\section{METODE PENELITIAN}

Penelitian ini menggunakan metode pendekatan kualitatif dengan jenis penelitian deskriptif. Sumber data yang digunakan adalah suber data primer dan sumber data sekunder. Informan dari penelitian ini adalah pemilik pengelolaan logam mulia dan anak usia sekolah yang bekerja di pengolahan logam mulia Desa Batu Putih Kecamatan Taliwang Kabupaten Sumbawa Barat.

Lokasi penelitian berada di Desa Batu Putih, Kecamatan Taliwang, Kabupaten Sumbawa Barat. Kemudian tempat penelitian berada di sekitar pertambaangan dan rumah-rumah yang dijadikan anak-anak sebagai tempat penghancuran.

Análisis data pada penelitian ini menggunakan análisis data deskriptif dimana proses analisis data dimulai dengan menelaah seluruh data yang tersedia dari berbagai sumber, yaitu dari wawancara, pengamatan atau observasi yang sudah dituangkan dalam catatan tertulis di lapangan, gambar atau foto. Kemudian langkah selanjutnya menganalisis data melalui empat langkah, yaitu pengumpulan data, reduksi data, penyajian data, dan penarikan kesimpulan atau verifikasi (Huberman, 1992). Selanjutnya tahaptahap penelitian terdiri atas tahap persiapan, tahap rancangan penelitian, tahap pelaksanaan, dan tahap pelaporan.

\section{HASIL DAN PEMBAHASAN}

1. Sejarah sektor pengolahan logam mulia di Desa Batu Putih Kecamatan Taliwang Kabupaten Sumbawa Barat

Proses berdirinya tambang rakyat menurut Siburian (2012), terjadi ketika adanya penemuan bahan galian oleh perusahaan pertambangan kemudian mengalami perkembangan pesat sehingga masyarakat disekitar pertambangan mencoba ikut nenambang. Hal ini serupa dengan pertambangan di Desa Batu Putih. Pertambangan tersebut berdiri pasca adanya penemuan kandungan emas oleh PT. Newmont pada tahun 1995. Melalui hal itu masyarakat sekitar mulai ikut mendirikan usaha perseorangan di bidang pertambangan yakni pengolahan logam mulia secara tradisional.

\section{Minat belajar remaja usia sekolah yang bekerja di sektor pengolahan logam mulia}

Keberadaan sentra industri batik sebagai IKM memberikan manfaat bagi masyarakat. Manfaat yang pertama, terbukanya lapangan pekerjaan.

Remaja usia sekolah di Desa Batu Putih memiliki minat untuk belajar. Remaja usia sekolah merasa tidak terganggu dengan aktivitas bekerja mereka di pengolahan logam mulia. Hal ini dikarenakan mayoritas remaja usia sekolah tersebut menganggap bekerja di pengolahan logam mulia sebagai pekerjan sampingan di samping aktivitas belajar mereka. Hal ini sesuai dengan hasil temuan dari Mardelina (2017) yang mengatakan bahwa, pekerjaan sampingan atau dikenal dengan istilah Part-time merupakan kerja paruh waktu yang dilakukan oleh siswa/ mahasiswa sebagai pekerjaan sambilan disamping tugasnya untuk belajar.

Perbedaan mampu dan tidaknya belajar oleh para remaja di Desa Batu Putih pada dasarnya ditentukan oleh kemampuan dalam memanagemen waktu. Remaja yang mampu memanajemen waktu belajar dengan baik menjadikan remaja usia sekolah tersebut mampu mengatur aktivitas belajar. Walaupun ia memiliki aktivitas lain yakni sebagai pekerja pengolahan logam mulia. Hal ini sesuai dengan hasil temuan oleh Mulyadi (2015), bahwa siswa yang memiliki keterampilan memanajemen waktu dengan baik cenderung mendapatkan hasil belajar yang baik. Sedangkan bagi mereka yang tidak mampu mengatur aktivitas belajar dengan pekerjaannya, maka akan kesulitan untuk melakukan aktivitas belajar tersebut. Ahmadi (2004) mengatakan bahwa siswa yang sekolah sambil bekerja dan tidak mampu mengatur kedua aktivitas tersebut maka konsentrasi untuk belajar terpecah dan membuat hasil belajarnya menurun (rendah).

3. Kontribusi ekonomi remaja yang bekerja sambilan di pengolahan logam mulia terhadap kelanjutan pendidikannya

Bekerja di pengolahan logam mulia membuat para remaja Desa Batu Putih dapat memenuhi kebutuhan sehari-harinya. Mereka 
mampu memenuhi kebutuhan sehari-hari mereka dari upah yang mereka peroleh dari bekerja. Menurut Sari dkk (2009), upah adalah suatu penerimaan imbalan yang diterima oleh pekerja atas jasa yang telah dilakukan, dimana upah tersebut berfungsi sebagai alat untuk memenuhi kebutuhan hidup. Hal inilah yang membuat para remaja bisa memenuhi kebutuhan sehari-hari.

Selain dapat memenuhi kebutuhan seharihari, mereka juga dapat meringankan beban ekonomi orang tua dalam hal uang saku. Hal tersebut sesuai dengan pendapat Suyanto (2003) yang mengatakan bahwa remaja yang mampu memenuhi kebutuhannya sehari-hari adalah remaja yang memiliki tanggung jawab terhadap dirinya sendiri, dan secara tidak langsung memberi keringanan para orang tua dalam memenuhi kebutuhan anaknya. Walaupun para remaja yang bekerja memiliki penghasilan sendiri, mereka tetap memperoleh finansial dari orang tua.

Adapun sebagian remaja yang melanjutkan sekolahnya karena hasil dari ia bekerja di pengolahan logam mulia disebabkan oleh keadaan perekonomian keluarganya tergolong kurang mampu. Menurut Kustiasih (2011), anakanak atau remaja usia sekolah yang bekerja demi bisa melanjutkan pendidikan mereka dikarenakan perekonomian keluarga mereka yang tidak mencukupi untuk membiayai sekolah. Adanya tekat yang tinggi untuk tetap bersekolah akan tetapi dengan keadaan ekonomi yang serba kekurangan memaksa mereka harus bekerja demi bisa membantu orang tua mencari nafkah dan sebagian hasilnya digunakan untuk membiayai kebutuhan sekolah mereka sendiri.

\section{KESIMPULAN DAN SARAN}

\section{A. KESIMPULAN}

logam mulia di Desa Batu Putih Kecamatan Taliwang Kabupaten Sumbawa Barat terhadap minat belajar remaja sekolah melanjutkan pendidikannya diketahui bahwa sejarah usaha pengolahan logam mulia di Desa Batu Putih bermula dari PT. Newmont menemukan kandungan emas di daerah lain pada tahun 1995. Hal ini yang membuat masyarakat Desa Batu Putih dibantu oleh para pendatang dari luar Pulau Sumbawa ikut mendirikan usaha pengolahan logam mulia secara tradisional dalam sekala besar. Seiring dengan berjalannya waktu, pengolahan logam mulia diminati oleh masyarakat sekitar sehingga masyarakat mendirikan pengolahan logam mulia dalam sekala kecil atau dengan sebutan pengolahan logam mulia rumahan.

Sebagian besar remaja usia sekolah yang bekerja di pengolahan logam mulia memiliki minat belajar yang baik. Ada beberapa alas an yang membuat remaja usia sekolah memiliki minat belajar yang baik yaitu (1) menganggap bekerja di pengolahan logam mulia sebagai pekerjaan sampingan di luar aktivitas belajar, (2) remaja usia sekolah tetap memiliki fokus terhadap beban akademik sekolah. Selain dua hal tersebut, manajemen waktu antara belajar dan bekerja juga sangat mempengaruhi baik atau buruknya minat belajar para remaja.

Remaja usia sekolah yang bekerja di pengolahan logam mulia tidak memiliki kontribusi yang signifikan terhadap kelanjutan pendidikannya,. Hal ini dikarenakan biaya untuk melanjutkan pendidikan mereka dapatkan murni dari orang tua.

\section{B. SARAN}

Berdasarkan uraian hasil penelitian terhadap kontribusi ekonomi pengolahan logam mulia di desa batu putih kecamatan taliwang kabupaten sumbawa barat terhadap minat remaja sekolah melanjutkan pendidikannya, peneliti memberikan saran bagi pemerintah Kabupaten Sumbawa Barat supaya diadakannya peningkatan program wajib belajar, bagi masyarakat Desa Batu Putih terutama bagi para orang tua agar memfokuskan anak mereka untuk belajar di sekolah tanpa harus ikut atau melibatkan anak bekerja agar anak mereka bisa fokus untuk belajar, Saran bagi remaja yang bekerja agar mengurangi bekerja bila perlu berhenti dan fokus belajar agar hasil belajar memuaskan dan tidak merasa kelelahan pada malam harinya, Saran peneliti kepada Program Studi S1 Pendidikan IPS adalah dengan menjadikan hasil penelitian ini sebagai salah satu refrensi mata kulia kajian kemiskinan atau mata kuliah lain bidang sosial, kepada peneliti selanjutnya dapat melakukan kajian penelitian serupa tentang pengaruh sosial ekonomi keluarga terhadap kelanjutan pendidikan remaja usia sekolah di Desa Batu Putih.

\section{DAFTAR PUSTAKA}

Ahmadi, Abu. \& Supriyono, Widodo. 2004. Psikologi Belajar. Jakarta: Rineka Cipta

Huberman, A. Michael \& Miles, Matthew. 1992. Analisis Data Kualitatif: Buku

Sumber Tentang Metode-Metode Baru. Jakarta: UI Press 


\begin{tabular}{|c|c|c|c|c|}
\hline $\begin{array}{c}\text { Focus: Jurnal } \\
\text { Pekerjaan Sosial }\end{array}$ & ISSN: $2620-3367$ & Vol. 2 No: 2 & Hal: $174-177$ & Desember 2019 \\
\hline
\end{tabular}

Kustiasih, R. 24 Juli 2011. Mereka Harus Bekerja Keras untuk Bisa Sekolah. Kompas. Dari http://lifestyle.kompas.com

Mardelina, Elma. \& Muhson, Ali. 2017. Mahasiswa Bekerja dan Dampaknya Pada Aktivitas Belajar dan Pretasi Akademik. Jurnal Economica, 13 (2) 201-209. Dari https://journal.uny.ac.id/index.php/economi a/article/view/13239

Mursalin. Sulaiman. \& Nurmasyitah. 2017. Peran Guru dalam Pelaksanaan Manajemen Kelas di Gugus Bungong Seulanga Kecamatan Syiah Kuala Kota Aceh. Jurnal Ilmiah Pendidikan Guru Sekolah Dasar, 2 (1) 105$114 . \quad$ Dari http://www.jim.unsyiah.ac.id/pgsd/article/vi ew/2538

Sari, L., Eriyati., \& Yanita, I. 2009. Analisis Tingkat Upah Pekerja di Kota Pekan Baru (Studi Kasus Rumah Makan/ Restoran). Jurnal Ekonomi, 17 (2) 87-95. Dari https://ejournal.unri.ac.id/index.php/JE/arti cle/view/725/718

Siburian, Robert. 2012. Pertambangan Batu Bara: Antara Mendulang Rupiah dan Menebar Potensi Konflik. Jurnal Masyarakat Indonesia 38 (1) 69-92. Dari http://ejournal.lipi.go.id/index.php/jmiipsk/ article/view/297

Suyanto, Bagong. 2003. Pekerja Anak dan Kelangsungan Pendidikannya. Surabaya: Airlangga University Press 